\title{
Influence of Time on Bond Characteristics Between Extruded PVC Tube and Cast HTPB/IPDI Rocket Propellant
}

\author{
Jovan Radulovic ${ }^{1)}$ \\ Aleksandar Milojković ${ }^{1)}$
}

\begin{abstract}
This paper is dealing about the possibility of using thermoplastic material as an inhibitor for solid composite propellant in a long period of time. A basic point in this consideration is an analysis of bond characteristics between the extruded PVC tube and cast HTPB/IPDI rocket propellant examined immediately after the production of samples and after a long period of storage. Structure of poly(vinyl chloride), extrusion technology, hydroxy-terminated polybutadiene and casting technology are presented. Tested characteristics of samples of the extruded PVC tube-cast HTPB/IPDI propellant were bond strength and visual appearance of separated parts. Determination of the bond strength and visual appearance of samples were done at $20^{\circ} \mathrm{C}$ and $50^{\circ} \mathrm{C}$. These characteristics of the extruded PVC tube-cast HTPB/IPDI propellant bond were determined at freshly prepared samples and at samples after five years of storage in warehouse conditions, at both above stated temperatures.
\end{abstract}

Key words: polymeric materials, poly(vinyl) chloride, hidroxyl terminated polybutadiene, extrusion, tube, thermoplastic materials, solid rocket propellant, cast propellant, inhibitors, bond, ageing, influence of time.

\section{The list of abbreviations used in the paper}

$S 1, S 2$, - designations of the extruded PVC tube-cast $S 3 \quad$ HTPB/IPDI rocket propellant samples tested at Start,

$A 1, A 2$, - designations of the extruded PVC tube-cast

A3 HTPB/IPDI rocket propellant samples tested after Ageing,

$x_{i} \quad$ - single value of the extruded PVC tube-cast HTPB/IPDI rocket propellant bond strength and

$\left(x_{i} \pm \delta\right)$ - arithmetic mean value and standard deviation of the extruded PVC tube-cast HTPB/IPDI rocket propellant bond strength

\section{Introduction}

AN has worked hard from the earliest times to develop synthetic materials which would offer benefits not found in the natural products around him.

Relative importance of some kind of materials in a long period of time is presented in Fig. 1, from which it can be seen that polymeric materials had an appropriate importance in ancient times and in present, especially since year 2000. [1].

In this paper data about bond characteristics between rigid PVC tube, obtained by extrusion technology, and HTPB based propellant, cast into mentioned tube, are presented.

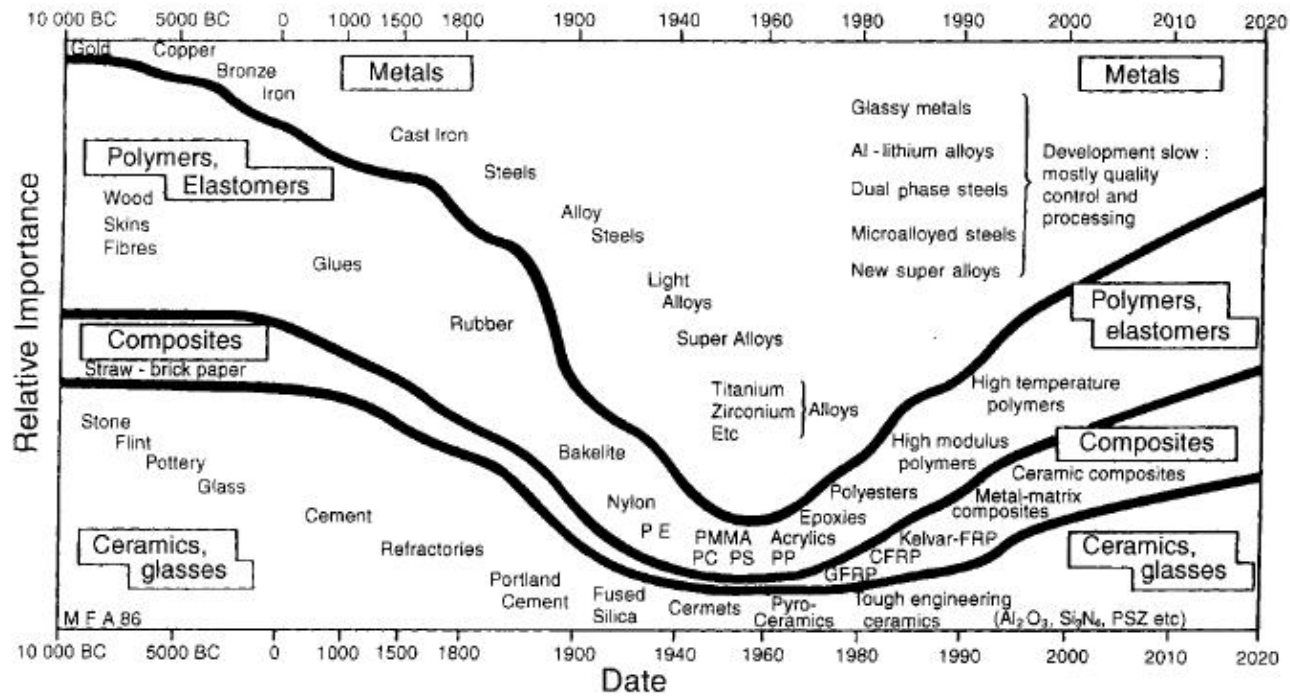

Figure 1. Relative importance of some materials classes in a long period of time

\footnotetext{
1) Military Technical Institute (VTI), Ratka Resanovića 1, 11132 Belgrade, SERBIA

Correspondence to: Jovan Radulović; e-mail: jovan.r.radulovic@gmail.com
} 


\section{PVC and EXTRUSION, HTPB and CASTING}

Poly(vinyl chloride) was first discovered accidentally in 1835 by a French chemist and physicist Henry Victor Regnault and in the early 20th century the Russian chemist Ivan Ostromislensky patented the synthesis of poly(vinyl chloride) [2]. Poly(vinyl choride) (PVC) is one of the oldest polymeric synthetic materials with the longest history in industrial production [3].

In shortest, poly(vinyl chloride) is produced using addition polymerization reaction from vinyl chloride monomer by free radical mechanism (Fig.2):
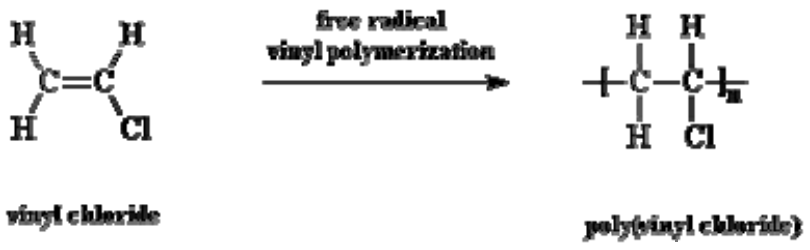

Figure 2. Production of poly(vinyl chloride)

Firstly synthetized PVC could not be processed because it was too brittle. Since PVC has a high polarity and high compatibility with a variety of plastic materials and additives, it is possible to mix these ingredients easily into polymer and to obtain compound that can be processed by an appropriate technology. Main techniques for overcoming some of the PVC shortages are presented in Fig.3 [4].

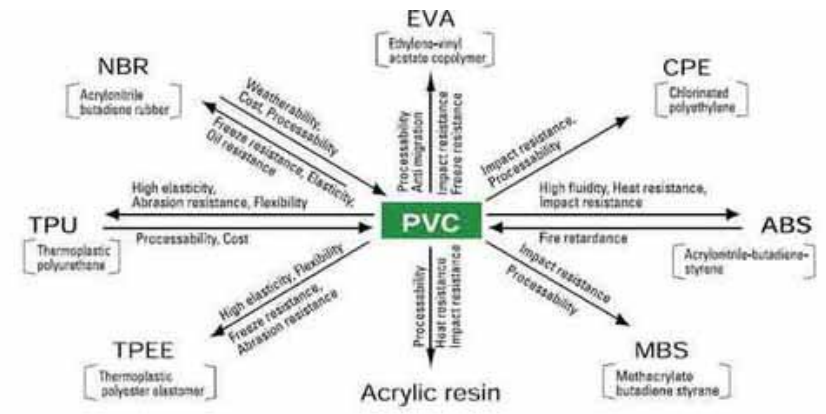

Figure 3. Main techniques for overcoming some of the PVC shortages

The application of heat and pressure will cause PVC to soft and take on new shapes. PVC is used to make electrical cable coverings, hoses, cold and hot water tubes, floor plates, shoes parts, leather-look clothing, storage containers, credit cards, etc. [4]

PVC based compounds can be processed by extrusion, calendaring, injection molding, impregnation, blow molding, etc.

For the tube extrusion a mixture of PVC resin and a corerspondent additives, i.e. stabilizers, fillers, lubricants, pigments and modifiers are used [5].

PVC resin is the most important ingredient of PVC product. The characteristics of PVC products depend on mean molecular mass and additives. PVC resin has a wide range of molecular weights and average molecular mass is expressed as a $\mathrm{K}$ value (introduced 1930 by Fikentscher) in Europe, as an inherent viscosity (I.V.) in the United States or as a degree of polymerization (D.P.) in Japan [6].

Stabilizers are one of the most crucial additives. PVC is a heat and light sensitive material. PVC compounds are exposed to the heat influence during homogenization of ingredients and extrusion. Light influence exists during weathering of PVC product. The stabilizer is added to prevent heat degradation so that the PVC compound can be formed into a product before it degrades. Stabilizers in tube extrusion are used mainly to protect the PVC in the hot hostile environment of the extruder. Widely used stabilizers are organotin mercapto esters because they give good heat and light resistance, color stability, promote fusion and reduce melt viscosity [7].

Fillers, used in PVC compounds, are mainly metal carbonates and silicates. The most common is calcium carbonate coated with stearic acid. The coating reduces the abrasiveness of the calcium carbonate and reduces extruder barrel and screw wear. Calcium carbonate can be used in PVC compounds to lower the raw material cost and contributes to economic aspect of the finished compound [8].

Lubricants serve to decrease frictional forces between polymeric chains because thermoplastics polymers tend to be relatively viscous and sticky above their melt temperature. Also, these additives, decrease friction between polymer ingredients and metal surfaces of the process equipment.

External lubricants provide a good release from metal surfaces and lubricate surfaces between the individual PVC particles and the metal surface. These kinds of lubricants are normally non-polar molecules, usually paraffin waxes. It helps the PVC slip over the hot melt surfaces of the barrels, screws and dies without sticking and contribute to the gloss on the end product surface.

Internal lubricants are normally polar molecules which reduce friction occurring between the molecular chains of PVC, thus lowering the melt viscosity. Also, these additives reduce internal friction, promote fusion and have a low tendency for exudation, which could impair the capability of bonding with other materials. A lubricant combination, consisting of a paraffin wax, calcium stearate and oxidized PE wax, is well suited for the PVC tube extrusion [9].

Pigments in PVC compounds are used for UV protection and for a given color of product. Titanium dioxide is the major pigment used. In colored PVC compounds a mixture of rutile type titanium dioxide and other appropriate pigments are used [8].

Processing additives for PVC are acrylic polymers, as indicated in Fig.3. These ingredients in PVC compounds promote fluxing and act like internal lubricants. Acrylic polymers allow good retention of properties with good color retention of the extruded PVC elements and contribute to heat and impact resistance of PVC products [8].

Extrusion is, in the shortest, a process used to create objects of a fixed cross-sectional profile. The extrusion is a compression process in which material is forced to flow through a die orifice to provide long continuous product whose cross-sectional shape is determined by the shape of the orifice.

The two main advantages of this process, over other manufacturing processes, are its ability to create very complex cross-sections and work materials that are brittle, because the material only encounters compressive and shear stresses [10].

The extrusion may be continuous (theoretically producing indefinitely long material) or semi-continuous (producing many pieces). The extrusion process can be done with the material hot or cold. Commonly extruded materials include metals, polymers, ceramics, concrete and foodstuffs are, also, extruded.

In 1797, Joseph Bramah patented the first extrusion process for making lead tube. In 1894, Alexander Dick expanded the extrusion process to copper and brass alloys [11].

During the past fifty years, development of more effective stabilizers, lubricants, and processing aids, together with processing machinery engineered specifically for PVC, allowed for increasing success in the extrusion of quality, 
rigid, unplasticized PVC tube. The result was that PVC tube began competing with traditional products in a number of classic and in some new markets [12].

Typical plastic materials that are used in extrusion include: poly(vinyl chloride), polyethylene, polypropylene, polybutylene, polyacetal, polyacrylic, polyamides, polystyrene, acrylonitrilebutadiene styrene and polycarbonate [13].

In shortest, during polymer extrusion, compound (in pellet or powder form) is fed in an extrusion barrel where it is heated, melted and then forced to flow to the front of the barrel by means of a rotating screw. At the front of the barrel, the molten plastic leaves the screw and travels through a wire meshes and breaker plate. After passing through the breaker plate, molten plastic enters the die, which gives the final product profile. The cooling of a product is usually achieved by pulling the extrudate through a water bath [12-14].

Hydroxyl-terminated polybutadiene (HTPB) is an oligomer of butadiene, terminated at each end with a hydroxyl functional group. In shortest, HTPB is produced in addition polymerization reaction from 1,3 butadiene, as presented in Fig.4.

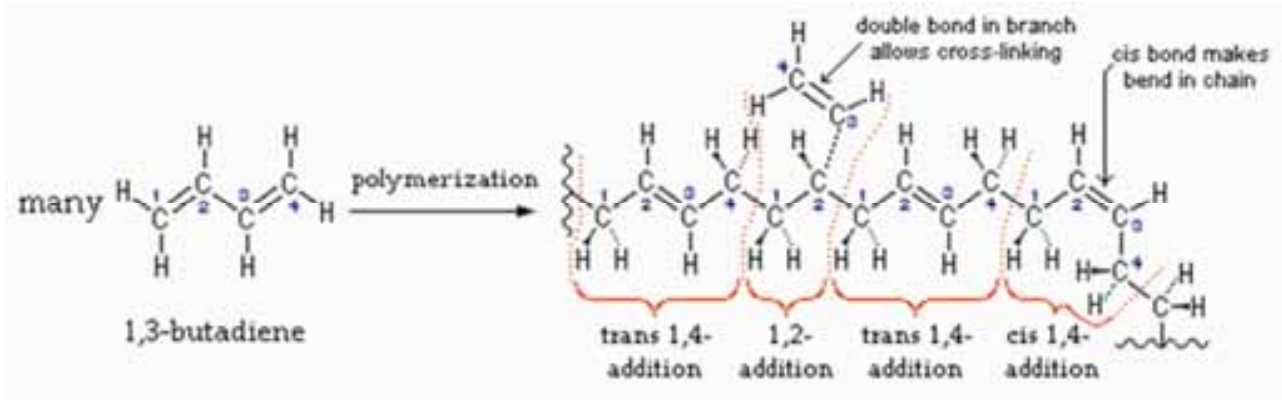

Figure 4. Production of hydroxyl-terminated polybutadiene

HTPB is rather a mixture of more reaction products than a pure compound. For example, HTPB designated as R45HTLO consists of oligomeric units typically containing 4050 butadiene molecules bonded together, with each end of the chain terminated with a hydroxyl group. HTPB is usually cured by an addition reaction with di- or poly-isocyanate compounds to form polyurethane polymers [15].

Composite rocket propellants consist of an organic binder, inorganic oxidizer, metal fuel, plasticizer, stabilizer (antioxidant) and bonding agent [16].

The organic binder (polymer matrix) holds the composition together and acts as a fuel component, also. Once cured, the binder makes the propellant flexible, which decreases the possibilities of the propellant fractures under stress and pressure. The binder consists of at least two components. The first one is a liquid prepolymer and the second one is a curing agent. Liquid prepolymers are hydroxyl-terminated polybutadiene (HTPB), hydroxyl-terminated polyether (HTPE) and carboxyl-terminated polybutadiene (CTPB). Curing agents are isophorone diisocyanate (IPDI), 4,4'methylene-bis(cyclohexyl isocyanate) (HMDI), toluene diisocyanate (TDI). HTPB/IPDI system is extensively used in composite solid propellants, due to the convenient reaction conditions and relative lack of adverse side reactions. In a broad sense, HTPB based composite rocket propellant could be concerned as a weakly crosslinked thermosetting polyurethane system [17].

An inorganic oxidizer is a major component in propellant, by weight and volume. This component produces the high energy of combustion. Commonly used oxidizers are ammonium perchlorate, ammonium nitrate and potassium nitrate. Ammonium perchlorate is used most often due to its high energy, ability to oxidize commonly used fuels, variable burn rate, low cost and high availability. The multimodal combination of ammonium perchlorate particles provides optimum balance between the exposed oxidizer surface area and packing fraction, both of which impact burn rate [18].

Metal fuels such as aluminum and boron are frequently added to propellant mixtures. Aluminum, one of the widely used metal additives, is utilized in a wide variety of solid propellants. Addition of metal fuel increases the heat of combustion, propellant density and combustion temperature [18].
A plasticizer is a relatively low-viscosity organic liquid, which improves the rheological properties during processing, reduce the viscosity and extend the pot life of the propellant system. Addition of plasticizer also contributes to the thermal energy on oxidation. Most commonly used plasticizers are dioctyladipate (DOA), dioctylsebacate (DOS) and isodecylpelargonate (IDP) [19].

Antioxidants should be added to prevent oxidative hardening of propellants. Hydroxyl bonding sites in the prepolymer are not completely exhausted during crosslinking. Accordingly, the composite propellant is subjected to oxidative hardening and other contaminant reactions during storage. Some of the mostly used antioxidants are phenyl- $\beta$ naphtylamine and 2,2-methylene-bis-(4-methyl-6-tertbutylphenol) [17].

A bonding agents are surface active agents, which improved the adhesion between solid particles and the polymeric matrix and hence the mechanical properties of propellants. These propellant components produce an interaction between the oxidizer particles and the polymeric binder by forming primary or secondary bonds with the oxidizer and a primary bond with a binder. Bonding agents have been developed and they are typically used in (HTPB)based composite propellants since these polymers are weakly polar. Typical bonding agents are triethylenetetramine (TET), tris-1- (2-methyl aziridinyl) phosphine oxide (MAPO) and tetraethylenepentamine acrylonitrile glycidol adduct (TEPANOL) [20].

In polymer shaping, casting involves pouring of a liquid resin into a mould, using gravity to fill the cavity and allowing a polymer to harden [14].

\section{Basic considerations}

One of the most significant challenges in rocket motor construction is to develop an effective, well-engineered propellant inhibitor. An inhibitor should ensure no burning of inhibited area which leads to a controlled burning and protects the rocket case. Otherwise, the case would have been exposed to hot combustion products [21].

The inhibitor is simply a layer of heat resistant material that is bonded to one -or more- surfaces of a propellant grain 
and has a primary purpose of preventing combustion from occurring on that particular surface. Properties that are required for an effective inhibitor are: good bonding characteristics, low thermal conductivity, resistance to thermal degradation, resistance to creep in the presence of gas flow, low cost and availability.

Elastomeric based materials are mostly used as a solid propellant inhibitor. Data about appliance of thermoplastic materials as a solid propellant inhibitor was not found in the available literature. Extruded PVC products are rarely used with energetic materials, such as propellant.

In one of a few articles concerning this area, Bors et al. [22] investigated the effect of low explosive fillers (i.e. specific Pyrodex black powder and double-base smokeless powder) on pipe bomb containers materials (i.e. PVC, black steel and galvanized steel). They concluded that steel devices ruptured and exploded more quickly and generated fewer and larger fragments than did the PVC devices.

In other paper [23], same authors investigated devices composed of various pipe materials (PVC, black steel, and galvanized steel) filled with two different propellants (Pyrodex specific black powder and low energetic smokeless Alliant Red Dot powder). Devices were initiated and experimentally observed using high-speed videography. The results demonstrated a correlation between the type of energetic filler and both the size and velocity of the fragments [23].

The plasticizer is not chemically bonded in a propellant and can diffuse from it, so Libardi et al. studied a diffusion of plasticizer in a solid rocket motor's bond line. They concluded that the diffusion process begins at the early stages of curing. Results of investigation of freshly prepared and aged specimen showed the softening of the propellant on the layer located at $3 \mathrm{~mm}$ from the bondline. The changes can cause damages mainly to the bondline, thereby affecting the performance and security of the rocket motor [24].

This paper is dealing about the possibility of using thermoplastic material as an inhibitor for cartridge loaded composite solid propellant in a long period of time. A basic point in this consideration is an analysis of the bond characteristics between the extruded PVC tube and cast HTPB/IPDI-based composite rocket propellant examined immediately after production and after long period of storage. PVC, extrusion technology, hydroxyl-terminated polybutadiene and casting technology are, shortly, presented. Tested characteristics of the samples extruded PVC tube-cast HTPB/IPDI propellant were bond strength and visual appearance of separated parts. Determination of bond strength and visual appearance of the mentioned samples were done at $20^{\circ} \mathrm{C}$ and $50^{\circ} \mathrm{C}$. These characteristics of extruded PVC tubecast HTPB/IPDI propellant bond were determined for freshly prepared samples and for samples after five years storage in warehouse conditions, at both above stated temperatures.

\section{Experimental part}

The choice of ingredients in a compound for production PVC tube was done having in mind needed bond characteristics and restrictions concerning of used basic thermoplastic material, extrusion technology and solid propellant.

Compound for PVC tube extrusion consists of PVC K67, titanium dioxide, calcium carbonate, organotin mercapto esters, paraffin wax, calcium stearate, oxidized PE wax and acrylics. Production of extruded PVC tube was done on twin screw counter rotating extruder with cooling system with vacuum bath RWN 1 produced by Cincinnati-Milacron, Wien, Austria.
The composite propellant, used for investigation in this paper, consists of a hydroxyl-terminated polybutadiene R45HTLO, isophorone diisocyanate, ammonium perchlorate, aluminum, dioctyl adipate, phenyl- $\beta$-naphtylamine and triethylenetetramine. The HTPB/IPDI propellant was produced using a Baker-Perkins planetary mixer.

Production of a bond between the extruded PVC tube and cast HTPB/IPDI propellant was done using casting technology by direct pouring of homogenized components of propellant into mentioned tube. The curing of the cast propellant was performed according to the appropriate procedure [16]. After a curing of propellant, by machining a part of PVC tube is removed and by this procedure a sample for bond characteristics investigation between the extruded PVC tube and cast HTPB/IPDI composite rocket propellant was obtained.

\section{Results}

The characteristics of the extruded PVC tube-cast HTPB/IPDI propellant bond were determined for freshly prepared sample and aged samples after five years of storage in warehouse. Results and figures concerning testing done in short time after preparing the samples are presented. These data have been marked as S (start) [25]. Results and figures concerning testing done after five years ageing of producing of the samples are presented, also. These data have a mark A (aged). A tested sample used for determining the extruded PVC tube-cast HTPB/IPDI propellant bond characteristics is shown in Fig.5.

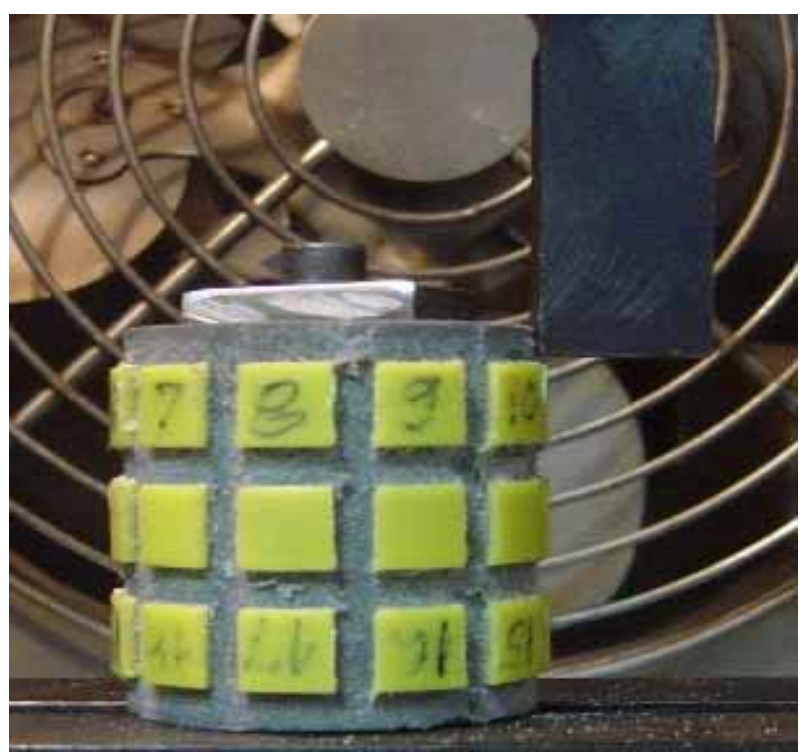

Figure 5. Sample for determining extruded PVC tube-cast HTPB/IPDI propellant bond characteristics

In Fig. 5 yellow square parts are pieces of the extruded PVC (dimensions $10 \mathrm{~mm} \times 10 \mathrm{~mm}$ ), a grey cylinder is a cast HTPB/IPDI propellant (external diameter 49,6 mm), and the black rectangular part is a special pusher. The extruded PVC tube-cast HTPB/IPDI propellant bond is exposed to the compressive stress from the upper side using the special pusher. The pusher has internal cylindrical area and flat lower area. The internal cylindrical surface of pusher, which is in direct contact with the external surface of a rocket propellant, has a radius which is equal to the external radius of the rocket propellant. Lower flat area of the pusher is in direct contact with an upper flat area of the PVC square part. Pusher, positioned on described manner, is acting on the extruded PVC tube-cast HTPB/IPDI propellant bond under the influence of compressive stress from the upper side. 
Described testing parameters are similar to those presented in standard for determining shear properties of bond [26].

Sample S1, just before the end of a testing of the extruded PVC tube-cast HTPB/IPDI propellant bond strength, is shown in Fig.6.

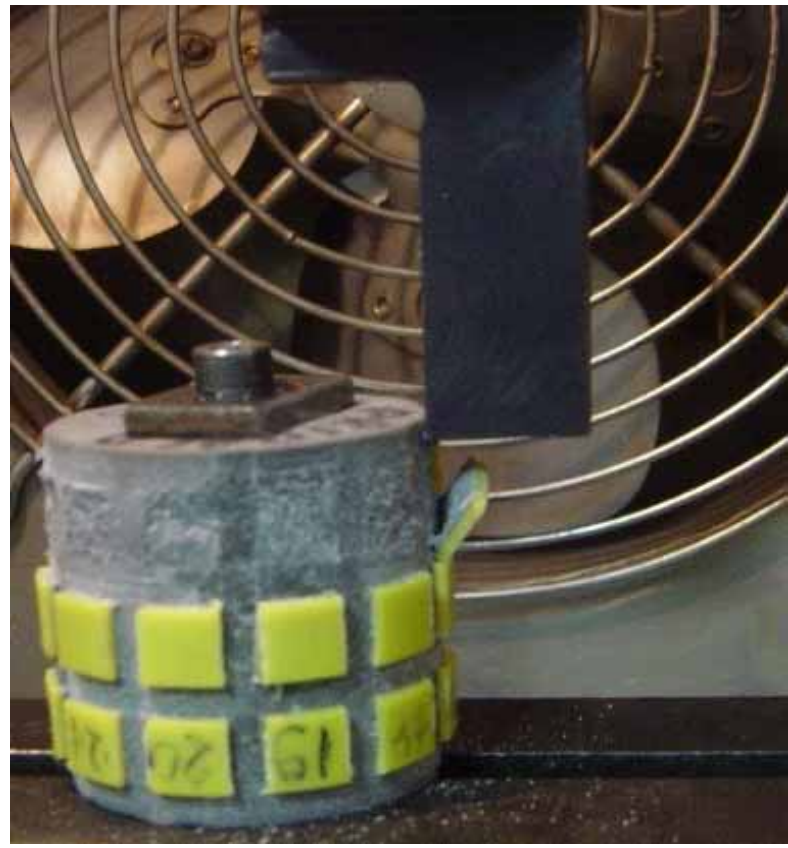

Figure 6.Sample $\mathbf{S} 1$ just before the end of testing of the extruded PVC tubecast HTPB/IPDI propellant bond strength

Determining of the extruded PVC tube-cast HTPB/IPDI propellant bond strength was carried out at $20^{\circ} \mathrm{C}$ and $50^{\circ} \mathrm{C}$. Bond mark (BM), single values for all 18 specimen $\left(x_{i}\right)$ and arithmetic mean value with standard deviations $\left(x_{i} \pm \delta\right)$ of the extruded PVC tube-cast HTPB/IPDI propellant bond strength for sample $\mathrm{S} 1$, determined at $20^{\circ} \mathrm{C}$, are shown in Table 1 .

Table 1. Extruded PVC tube-cast HTPB/IPDI propellant bond strength for sample $\mathrm{S} 1$ determined at $20^{\circ} \mathrm{C}$

\begin{tabular}{|c|c|c|c|c|c|c|c|c|c||}
\hline BM & 1 & 2 & 3 & 4 & 5 & 6 & 7 & 8 & 9 \\
\hline \hline$\left(x_{i}\right)(\mathrm{N})$ & 72.6 & 73.0 & 62.2 & 66.8 & 67.0 & 83.0 & 69.0 & 75.6 & 81.8 \\
\hline $\begin{array}{c}(\bar{x} \pm \delta) \\
(\mathrm{N})\end{array}$ & \multicolumn{10}{|c||}{$76,1 \pm 7,0$} \\
\hline
\end{tabular}

Table 1. Continued

\begin{tabular}{|c|c|c|c|c|c|c|c|c|c||}
\hline BM & 10 & 11 & 12 & 13 & 14 & 15 & 16 & 17 & 18 \\
\hline \hline$\left(x_{i}\right)(\mathrm{N})$ & 78.2 & 82.0 & 81.8 & 85.0 & 80.8 & 87.0 & 76.2 & 71.8 & 75.2 \\
\hline $\begin{array}{c}\left(x_{i} \pm \delta\right) \\
(\mathrm{N})\end{array}$ & \multicolumn{10}{|c|}{$76,1 \pm 7,0$} \\
\hline
\end{tabular}

Bond mark (BM), single values for all 12 specimen $\left(x_{i}\right)$ and arithmetic mean value with standard deviations $(\bar{x} \pm \delta)$ of the extruded PVC tube-cast HTPB/IPDI propellant bond strength for sample $\mathrm{S} 2$, determined at $20^{\circ} \mathrm{C}$, are shown in Table 2 .

Table 2. Extruded PVC tube-cast HTPB/IPDI propellant bond strength for sample S2 determined at $20{ }^{\circ} \mathrm{C}$

\begin{tabular}{|c|c|c|c|c|c|c|c|c|c|c|c|c||}
\hline BM & 1 & 2 & 3 & 4 & 5 & 6 & 7 & 8 & 9 & 10 & 11 & 12 \\
\hline \hline$\left(x_{i}\right)(\mathrm{N})$ & 80.6 & 76.8 & 62.6 & 74.2 & 79.6 & 78.2 & 77.2 & 72.0 & 73.8 & 78.6 & 85.3 & 72.6 \\
\hline \begin{tabular}{c|c}
$\bar{x} \pm \delta)$ \\
$(\mathrm{N})$
\end{tabular} & \multicolumn{10}{|c|}{$75.9 \pm 5.6$} \\
\hline
\end{tabular}

Bond mark (BM), single values for all 12 specimen $\left(x_{i}\right)$ and arithmetic mean value with standard deviations $(\bar{x} \pm \delta)$ of the extruded PVC tube-cast HTPB/IPDI propellant bond strength for sample $\mathrm{S} 2$, determined at $50^{\circ} \mathrm{C}$, are shown in Table 3 .
Table 3. Extruded PVC tube-cast HTPB/IPDI propellant bond strength for sample $\mathrm{S} 2$ determined at $50^{\circ} \mathrm{C}$

\begin{tabular}{|c|c|c|c|c|c|c|c|c|c|c|c|c|}
\hline $\mathrm{BM}$ & 1 & 2 & 3 & 4 & 5 & 6 & 7 & 8 & 9 & 10 & 11 & 12 \\
\hline \hline$\left(x_{i}\right)(\mathrm{N})$ & 68.0 & 64.4 & 61.0 & 64.4 & 60.0 & 58.6 & 68.6 & 71.8 & 68.4 & 62.4 & 57.2 & 62.4 \\
\hline $\begin{array}{c}\bar{x} \pm \delta) \\
(\mathrm{N})\end{array}$ & \multicolumn{10}{|c|}{$64.0 \pm 4.4$} \\
\hline
\end{tabular}

Arithmetic mean values of the extruded PVC tube-cast HTPB/IPDI propellant bond strength for sample $\mathrm{S} 1$ and sample S2, determined at $20^{\circ} \mathrm{C}$, are $76.1 \mathrm{~N}$ and $75.9 \mathrm{~N}$, respectively.

Arithmetic mean value of the extruded PVC tube-cast HTPB/IPDI propellant bond strength for sample S2, determined at $50^{\circ} \mathrm{C}$, is $64.0 \mathrm{~N}$.

By comparison of the obtained data for the same sample $\mathrm{S} 2$ bond strength, determined at temperatures $20^{\circ} \mathrm{C}$ and $50^{\circ} \mathrm{C}$, it can be seen that this parameter decreases with increasing temperature.

The same reduction of bond strength can be seen for sample $\mathrm{S} 1$ data, tested at temperature $20^{\circ} \mathrm{C}$ and for sample $\mathrm{S} 2$ data, tested at temperature $50^{\circ} \mathrm{C}$. In both above mentioned cases, reduction of the bond strength with increasing temperature from $20^{\circ} \mathrm{C}$ to $50^{\circ} \mathrm{C}$, concerning samples tested in a short time after producing, is about $15 \%$.

Concerning a bond nature, in principle, there are two possibilities :

- first is that separation of bonded parts happened at interphase, i.e. at the surface at which parts were bonded and that separate parts remained compact and

- second is that separation of bonded parts happened in a way that one part holds on a certain quantity of other part, i.e. that bond remains non-damaged and that one of the parts is separated in two pieces.

In the first case, it speaks about the adhesive way of part separation, and in the second about the so called cohesive way of part separation. In former, adhesion force between bonded parts is lower than the cohesive energy of one material and the cohesive energy of another material. In the latter, adhesion force between bonded parts is higher than the cohesive energy of one of bonded materials.

By a visual inspection of the separated parts of the bond between the extruded PVC tube and cast HTPB/IPDI propellant, it can be seen a cohesive way of separation in all single specimen at sample $\mathrm{S} 1$ after testing at $20^{\circ} \mathrm{C}$ (presented in Fig.7) and the same way of separation in all single specimen at sample $\mathrm{S} 2$ after testing at $50^{\circ} \mathrm{C}$ (presented in Fig.8).

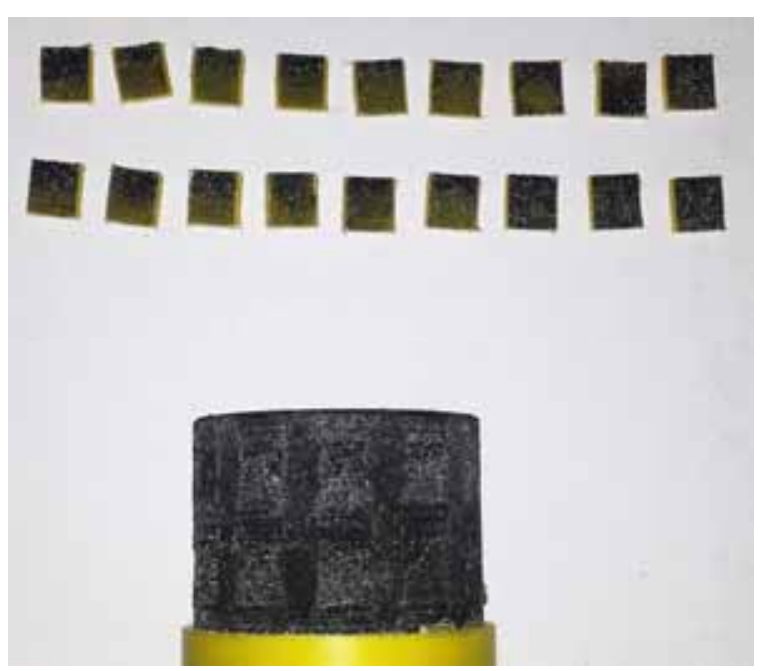

Figure 7. Visual appearance of all single specimen at sample $\mathrm{S} 1$ after testing at $20^{\circ} \mathrm{C}$ 

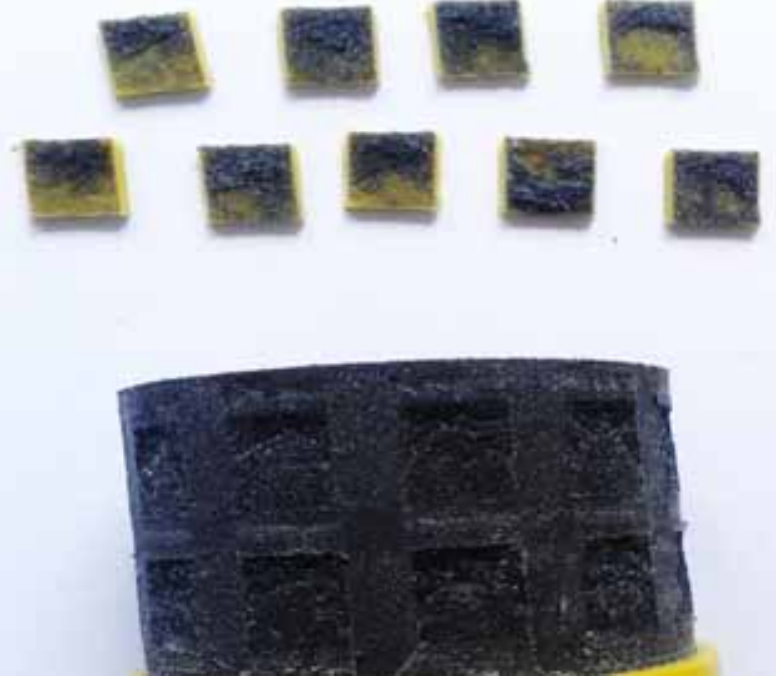

Figure 8. Visual appearance of all single specimen at sample $\mathrm{S} 2$ after testing at $50{ }^{\circ} \mathrm{C}$

The separated parts of the extruded PVC tube and cast HTPB/IPDI propellant of sample S1 and sample S2, after testing at $20^{\circ} \mathrm{C}(\mathrm{a})$ and $50^{\circ} \mathrm{C}(\mathrm{b})$, are shown in Fig.9.

By a visual inspection of separated parts it can be seen that on part of the extruded PVC tube there are fragments of cast HTPB/IPDI propellant. On the cast HTPB/IPDI propellant surfaces, which were in direct contact with extruded PVC tube pieces, fragments of this propellant are missing, too. A fragment of the propellant, which is on the separated PVC part, by size and configuration, completely responds to a fragment which is missing on the separated surface of the propellant. Separation within the cast HTPB/IPDI propellant happened near the interphase of mentioned tube and propellant and in a same manner at temperature $20^{\circ} \mathrm{C}$ and at temperature $50^{\circ} \mathrm{C}$. These surfaces are marked in Figures 9 (a) and $9(\mathrm{~b})$.

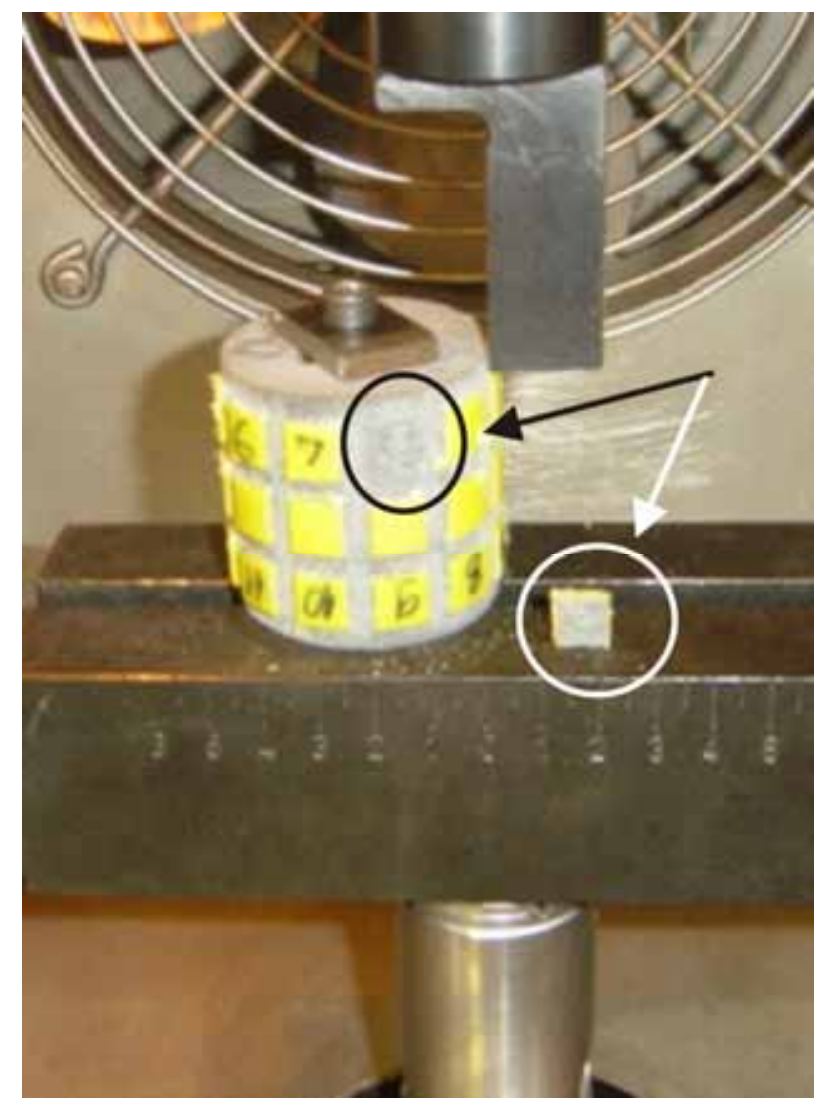

a)

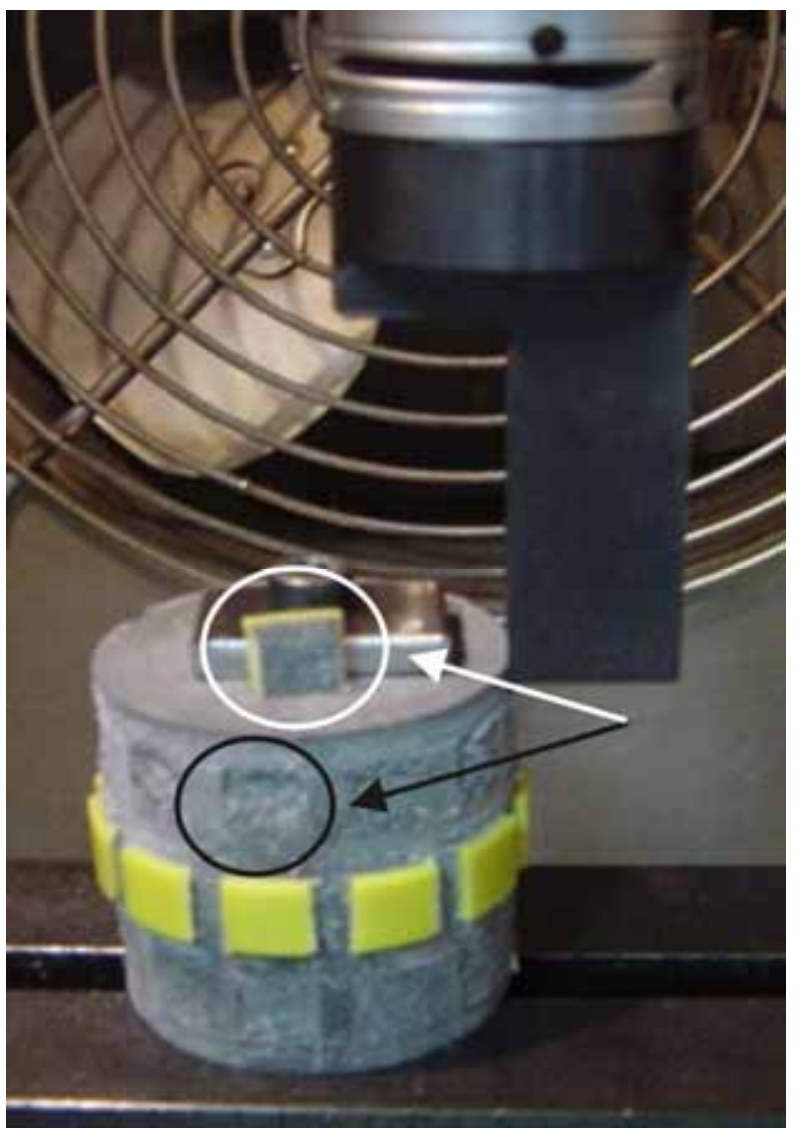

b)

Figure 9.The separated parts of the extruded PVC tube and cast HTPB/IPDI propellant of sample S1 and sample S2 after testing at $20^{\circ} \mathrm{C}$ (a) and $50{ }^{\circ} \mathrm{C}$ (b)

Obviously, cohesive separation of the bond is occurring because adhesive force of the extruded PVC tube-cast HTPB/IPDI propellant bond is higher than the cohesive energy within the tested solid propellant.

The thickness of propellant fragments on PVC parts of the start samples, after testing at $20^{\circ} \mathrm{C}$ and $50^{\circ} \mathrm{C}$, is from about 0.4 $\mathrm{mm}$ to about $1.8 \mathrm{~mm}$.

Testing of the characteristics of the extruded PVC tube-cast HTPB/IPDI propellant bond samples, after five years of ageing in warehouse conditions, was carried out at $20^{\circ} \mathrm{C}$ and $50^{\circ} \mathrm{C}$.

Bond mark (BM), single values of all 18 specimens $\left(x_{i}\right)$ and arithmetic mean value with standard deviations $\left(x_{i} \pm \delta\right)$ of the extruded PVC tube-cast HTPB/IPDI propellant bond strength for sample A1, determined at $20^{\circ} \mathrm{C}$, are shown in Table 4 .

Table 4. Extruded PVC tube-cast HTPB/IPDI propellant bond strength for sample A1 determined at $20{ }^{\circ} \mathrm{C}$

\begin{tabular}{|c|c|c|c|c|c|c|c|c|c||}
\hline BM & 1 & 2 & 3 & 4 & 5 & 6 & 7 & 8 & 9 \\
\hline \hline$\left(x_{i}\right)(\mathrm{N})$ & 84.62 & 75.42 & 77.59 & 78.67 & 78.92 & 78.65 & 78.42 & 78.57 & 75.11 \\
\hline $\begin{array}{c}(\bar{x} \pm \delta) \\
(\mathrm{N})\end{array}$ & \multicolumn{10}{|c}{$78.71 \pm 2.47$} \\
\hline
\end{tabular}

Table 4. Continued

\begin{tabular}{|c|c|c|c|c|c|c|c|c|c|}
\hline $\mathrm{BM}$ & 10 & 11 & 12 & 13 & 14 & 15 & 16 & 17 & 18 \\
\hline$\left(x_{i}\right)(\mathrm{N})$ & 80.02 & 80.04 & 82.55 & 81.53 & 77.64 & 77.30 & 79.46 & 76.89 & 75.48 \\
\hline $\begin{array}{c}(\bar{x} \pm \delta) \\
(\mathrm{N})\end{array}$ & \multicolumn{9}{|c|}{$78.71 \pm 2.47$} \\
\hline
\end{tabular}

In Table 5 are presented bond mark (BM), single values for all 9 specimens $\left(x_{i}\right)$ and arithmetic mean value with standard deviations $\left(x_{i} \pm \delta\right)$ of the extruded PVC tube-cast HTPB/IPDI propellant bond strength for sample $\mathrm{A} 2$ determined at $20^{\circ} \mathrm{C}$. 
Table 5. Extruded PVC tube-cast HTPB/IPDI propellant bond strength for sample A2 determined at $20^{\circ} \mathrm{C}$

\begin{tabular}{|c|c|c|c|c|c|c|c|c|c||}
\hline BM & 1 & 2 & 3 & 4 & 5 & 6 & 7 & 8 & 9 \\
\hline \hline$\left(x_{i}\right)(\mathrm{N})$ & 79.17 & 77.15 & 78.19 & 73.34 & 83.21 & 76.36 & 73.39 & 74.55 & 79.63 \\
\hline $\begin{array}{c}\bar{x} \pm \delta \\
(\mathrm{N})\end{array}$ & \multicolumn{10}{|c}{$76.36 \pm 3.58$} \\
\hline
\end{tabular}

In Table 6 are presented bond mark (BM), single values for all 9 specimens $\left(x_{i}\right)$ and arithmetic mean value with standard deviations $\left(x_{i} \pm \delta\right)$ of the extruded PVC tube-cast HTPB/IPDI propellant bond strength for sample $\mathrm{A} 2$ determined at $50^{\circ} \mathrm{C}$.

Table 6. Extruded PVC tube-cast HTPB/IPDI propellant bond strength for sample A2 determined at $50{ }^{\circ} \mathrm{C}$

\begin{tabular}{|c|c|c|c|c|c|c|c|c|c|}
\hline $\mathrm{BM}$ & 1 & 2 & 3 & 4 & 5 & 6 & 7 & 8 & 9 \\
\hline$\left(x_{i}\right)(\mathrm{N})$ & 64.48 & 64.42 & 64.48 & 66.58 & 66.47 & 65.19 & 64.86 & 63.87 & 65.23 \\
\hline$\left(\begin{array}{c}\bar{x} \pm \delta) \\
(\mathrm{N})\end{array}\right.$ & \multicolumn{9}{|c|}{$65.08 \pm 0.92$} \\
\hline
\end{tabular}

Bond mark (BM), single values of all 18 specimens $\left(x_{i}\right)$ and arithmetic mean value with standard deviations $\left(x_{i} \pm \delta\right)$ of the extruded PVC tube-cast HTPB/IPDI propellant bond strength for sample $\mathrm{A} 3$, determined at $50{ }^{\circ} \mathrm{C}$, are shown in Table 7 .

Table 7. Extruded PVC tube-cast HTPB/IPDI propellant bond strength for sample $\mathrm{A} 3$ determined at $50{ }^{\circ} \mathrm{C}$

\begin{tabular}{|c|c|c|c|c|c|c|c|c|c||}
\hline BM & 1 & 2 & 3 & 4 & 5 & 6 & 7 & 8 & 9 \\
\hline \hline$\left(\begin{array}{c}\left(x_{i}\right)(\mathrm{N}) \\
70.37\end{array}\right.$ & 66.44 & 66.89 & 69.63 & 69.46 & 69.44 & 67.11 & 68.30 & 69.07 \\
\hline $\begin{array}{c}(\bar{x} \pm \delta) \\
(\mathrm{N})\end{array}$ & \multicolumn{10}{c||}{$67.88 \pm 1.78$} \\
\hline
\end{tabular}

Table 7. Continued

\begin{tabular}{|c|c|c|c|c|c|c|c|c|c||}
\hline BM & 10 & 11 & 12 & 13 & 14 & 15 & 16 & 17 & 18 \\
\hline \hline$\left(x_{i}\right)(\mathrm{N})$ & 66.58 & 64.92 & 64.28 & 68.12 & 65.89 & 70.19 & 69.18 & 68.02 & 67.94 \\
\hline $\begin{array}{c}(\bar{x} \pm \delta) \\
(\mathrm{N})\end{array}$ & \multicolumn{10}{c}{$67.88 \pm 1.78$} \\
\hline
\end{tabular}

Arithmetic mean values of the extruded PVC tube-cast HTPB/IPDI propellant bond strength for sample A1 and sample $\mathrm{A} 2$, determined at $20^{\circ} \mathrm{C}$, are $78.71 \mathrm{~N}$ and $76.36 \mathrm{~N}$, respectively.

Arithmetic mean values of the extruded PVC tube-cast HTPB/IPDI propellant bond strength for sample A3 and sample A2, determined at $50^{\circ} \mathrm{C}$, are $67.88 \mathrm{~N}$ and $65.08 \mathrm{~N}$, respectively.

By comparison of the bond strength data determined at temperature $20^{\circ} \mathrm{C}$ (samples $\mathrm{A} 1$ and $\mathrm{A} 2$ ) and at temperature $50^{\circ} \mathrm{C}$ (samples $\mathrm{A} 3$ and $\mathrm{A} 2$ ), it can be seen that this parameter decreases with increasing temperature. A reduction of the bond strength with increasing temperature from $20^{\circ} \mathrm{C}$ to $50^{\circ} \mathrm{C}$, concerning the samples which were exposed to the ageing process lasting five years in warehouse conditions, is about $15 \%$.

After determination of the bond strength of the extruded PVC tube-cast HTPB/IPDI propellant samples A1, A2 and A3, by a visual inspection of separated parts, it was detected that on parts of the extruded PVC tube part there is a fragment of the propellant. The fragment of the propellant which remains on the tube part by size and configuration completely responds to a fragment which is missing on the separated surface of the propellant. Separation within solid propellant happened in a same manner at temperature $20^{\circ} \mathrm{C}$ (presented in Fig.10) and at temperature $50^{\circ} \mathrm{C}$ (presented in Fig.11).

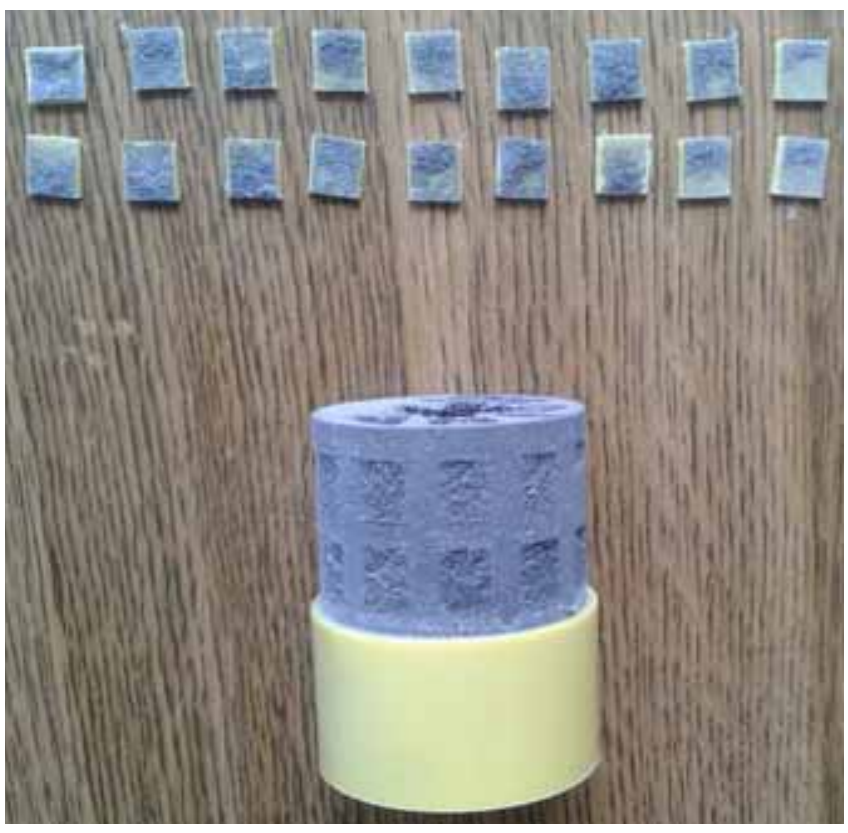

Figure 10. Appearance of all single specimen at sample A1 after testing at $20^{\circ} \mathrm{C}$

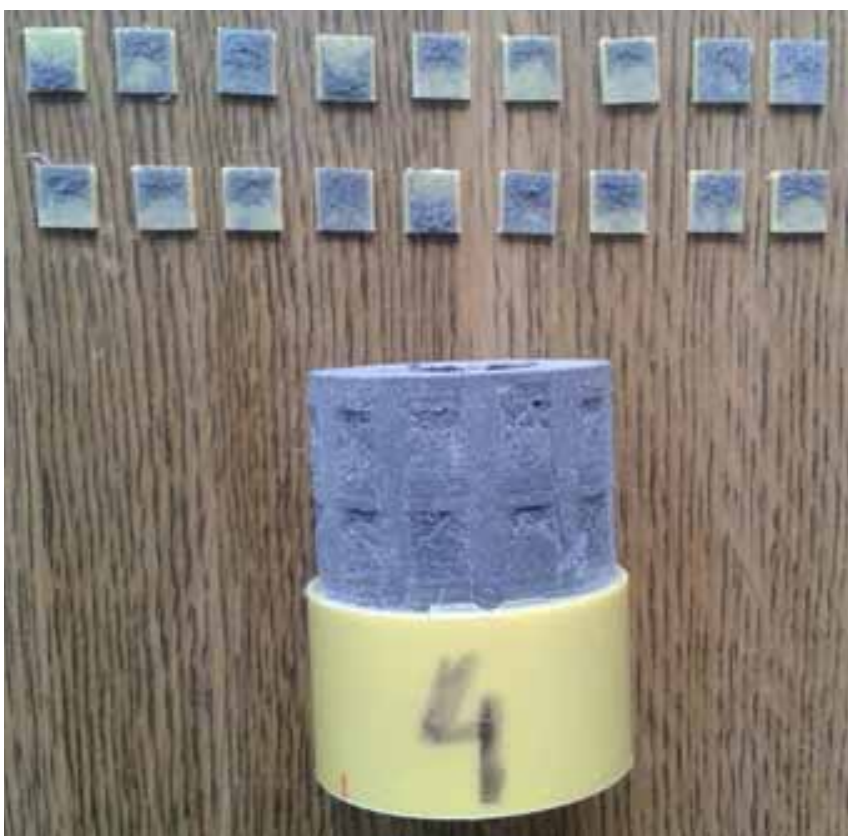

Figure 11. Appearance of all single specimen at sample A3 after testing at $50^{\circ} \mathrm{C}$

Cohesive separation of all specimen, tested after five years of ageing, were detected. It is obvious that adhesive force of the bond of aged samples of the extruded PVC tube-cast HTPB/IPDI propellant is higher than the cohesive energy within solid propellant at both afore mentioned temperatures.

The separated parts of the extruded PVC tube and cast $\mathrm{HTPB} / \mathrm{IPDI}$ propellant of sample A1, after testing at $20^{\circ} \mathrm{C}$ (a) and sample $\mathrm{A} 3$ after testing at $50^{\circ} \mathrm{C}(\mathrm{b})$, are shown in Fig. 12. A surface of the cast HTPB/IPDI propellant, where a fragment is missing, and a piece of the extruded PVC tube with a fragment of propellant, are clearly marked in Figures 12 (a) and 12 (b). 


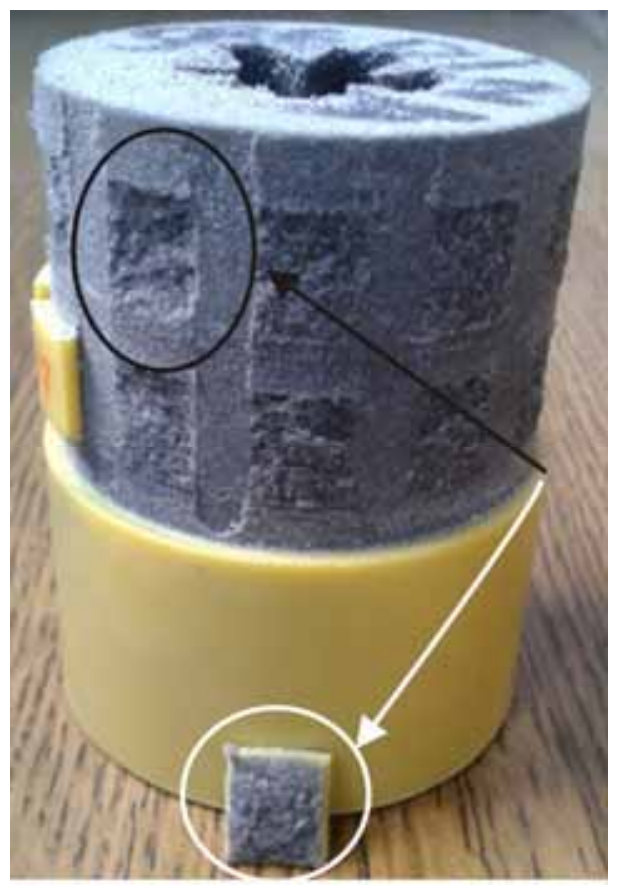

(a)

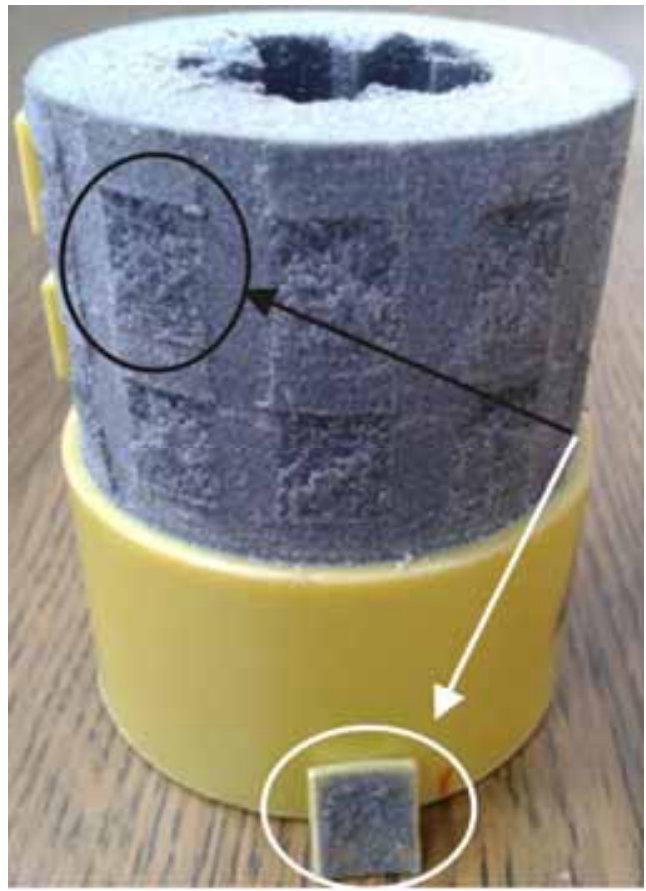

(b)

Figure 12. The separated parts of the extruded PVC tube and cast $\mathrm{HTPB} / \mathrm{IPDI}$ propellant of sample $\mathrm{A} 1$ after testing at $20^{\circ} \mathrm{C}$ (a) and sample $\mathrm{A} 3$ after testing at $50^{\circ} \mathrm{C}(\mathrm{b})$

The thickness of the propellant fragments on PVC parts of the aged samples, after testing at $20^{\circ} \mathrm{C}$ and $50^{\circ} \mathrm{C}$, is from about $0.4 \mathrm{~mm}$ to about $1.7 \mathrm{~mm}$.

Graphic dependence force-time of specimen number 16 (bond strenght $76.2 \mathrm{~N}$ ) of freshly prepared start sample S1 (Table 1), tested at $20^{\circ} \mathrm{C}$, and graphic dependence force-time for specimen number 4 (bond strength $78.7 \mathrm{~N}$ ) of sample A1 after ageing (Table 4), tested at $20^{\circ} \mathrm{C}$, are presented in Fig. 13.

In Fig. 14 are presented the graphic dependence force-time of specimen number 2 (bond strength $64.4 \mathrm{~N}$ ) of a sample S3, tested at $50^{\circ} \mathrm{C}$, short time after producing (Table 3 ) and the graphic dependence force-time of specimen number 18 (bond strength $67.9 \mathrm{~N}$ ) of a sample A3 after ageing, tested at $50^{\circ} \mathrm{C}$ (Table 7).

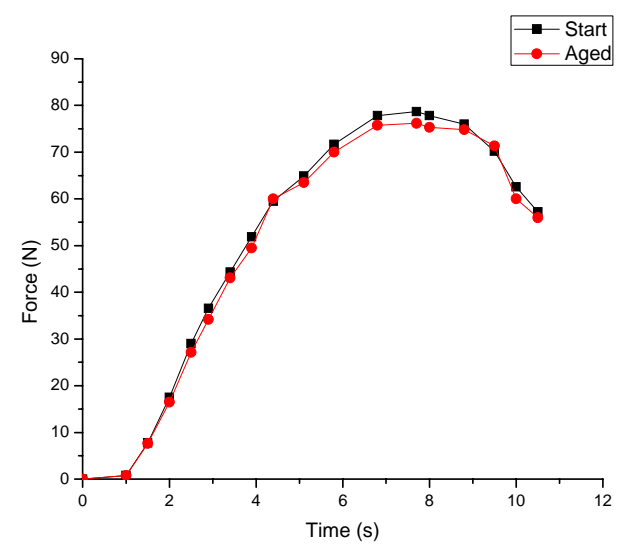

Figure 13. Graphic dependence force-time for fresh and aged specimen tested at $20^{\circ} \mathrm{C}$

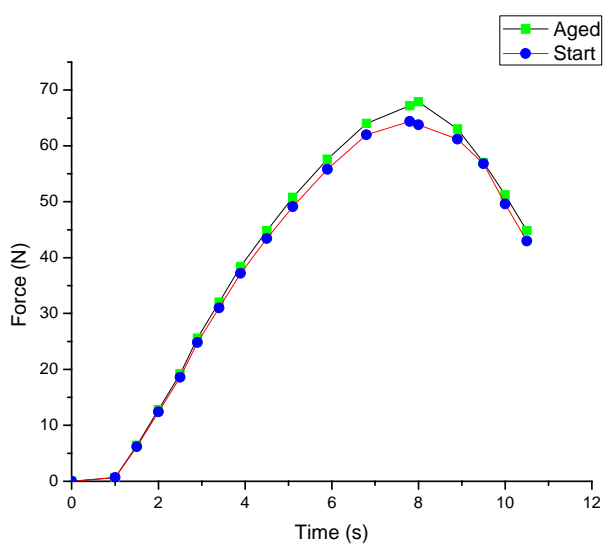

Figure 14. Graphic dependence force-time for fresh and aged specimen tested at $50^{\circ} \mathrm{C}$

From Fig. 13 (testing done at $20^{\circ} \mathrm{C}$ ) it can be seen that the graphic dependence force-time for specimen 16, tested at start, is similar to the graphic dependence force-time for specimen 4 , tested after five years of ageing.

Data in Fig. 14 (testing done at $50^{\circ} \mathrm{C}$ ) pointed out that there is a similarity between graphic dependence force-time for specimen 2, tested at start, and graphic dependence force-time for specimen 18, tested after five years of ageing.

\section{Conclusions}

1. The aim of this work was to evaluate the PVC tube HTPB/IPDI based composite propellant bond characteristics induced by natural ageing at ambient conditions during 5 years of storage. The results have shown that the period of five years of ageing in warehouse conditions has no influence on tested characteristics of the extruded PVC tube-cast HTPB/IPDI propellant bond.

2. Bond strength, at $20^{\circ} \mathrm{C}$, of freshly prepared samples is practically the same as the bond strength of aged samples. Values of $76.2 \mathrm{~N}$ (sample S1) and $75.9 \mathrm{~N}$ (sample S2) are obtained at start and values of $78.7 \mathrm{~N}$ (sample A1) and $76.4 \mathrm{~N}$ (sample A2) after five years of ageing.

3. The same situation is concerning the bond strength, at $50^{\circ} \mathrm{C}$. Value of $64.4 \mathrm{~N}$ (sample S2) is obtained at start and values of $65.1 \mathrm{~N}$ (sample A2) and 67.9 N (sample A3) after five years of ageing. 
4. Force-time dependences for the freshly prepared extruded PVC tube-cast HTPB/IPDI propellant samples are almost the same as those for aged samples.

5. Cohesive way of separation of the extruded PVC tubecast HTPB/IPDI propellant bond was observed for freshly prepared samples and samples after five years of storage.

6. A thickness of the propellant fragments on PVC parts at aged samples is almost the same as a thickness of the propellant fragments on PVC parts at freshly prepared samples.

\section{Reference}

[1] HAQ,I.U.: Composite materials, https://www.scribd.com/document/216816974/08-chapter1.

[2] OSTROMISLENSKY,I.: Polymer of vinyl chloride and process of making the same, U.S. Patent 1,721,034, 1929.

[3] www.pvc.org/en/p/history

[4] www.ausetute.com.au/pvc.html

[5] Handbook of PVC Pipe Design and Construction, Fifth Edition, December 2012, Published by, INC. 989 Avenue of the Americas New York, NY 10018

[6] HÜLSMANN,T., NOWACK,R.E.: 70 years of experience with PVC pipes, Industrial Press, www.teppfa.com

[7] http://w.patents.com/us-4058543.html. Organotin mercapto dicarboxylic acid esters and compositions

[8] www.quimsor.com.mx/catalogo/hojatechnicas/infotechnica/Ingredients Used in Rigid PVC

[9] http://sasolwax.us.com/pvc.html.

[10] OBERG,E., JONES,F.D., HORTON,H.L., RYFFEL,H.H.: Machinery's Handbook $\left(26^{\text {th }}\right.$ ed.), Industrial Press Inc., New York, 2000, ISBN 08311-2635-3.

[11] DROZDA,T., WICK,C., BAKERJIAN,R., VEILLEUX, R.F., PETRO,L.: Tool and manufacturing engineers handbook: Forming, 2, SME, 1984, ISBN 0872631354.

[12] Handbook of PVC Pipe Design and Construction, Fifth Edition, Industrial Press Inc., New York, 2012.

[13] TODD,R.H., ALLEN,D.K., ALTING,L.: Manufacturing Processes Reference Guide, Industrial Press Inc., 1994, ISBN 0-8311-3049-0,

[14] GROOVER,M.P.: Fundamentals of Modern Manufacturing, Materials, Processes and Systems, John Wiley \& Sons Inc, Hoboken, 2010.
[15] http://www.crayvalley.com/docs/TDS/poly-bd-r-45htlo.pdf. Technical Data Sheet: Poly bd® R-45HTLO

[16] BRZIĆ,S., RADULOVIĆ,J.: Dynamic-Mechanical Investigation of the Cured Filled Polymeric System of Hydroxyl Terminated Poly(Butadiene)/Isophorone Diisocyanate, Scientific Technical Review, ISSN 1820-0206, 2013, Vol.63, No.4, pp.32-39,

[17] AMTOWER,K.P.: Propellant Formulation, US Patent 7011722 B2, 2006.

[18] CHATURVEDI,S., DAVE,P.N.: Solid propellants: AP/HTPB composite propellants, Arabian Journal of Chemistry (2015), http://dx.doi.org/10.1016/j.arabjc.2014.12.033

[19] SEYIDOGLU,T., BOHN,M.A.: Effect of curing agents and plasticizers on the loss factor curves of HTPB-binders quantified by modeling, Proceedings of the $18^{\text {th }}$ International Seminar on New Trends in Research of Energetic Materials, Pardubice, Czech Republic, April 15.17., 2015, pp.794-815.

[20] CONSAGA,P.J.: Dimethyl Hydantoin Bonding Agents in Solid Propellants, US Patent 4214 928, 1980.

[21] Ackley A.W., Greenlee T.W., Gustavson C.: Bonding of composite propellant in cast-in-case rocket motors, Journal of Spacecraft and Rockets, 1996, Vol.3, No.3, pp. 413-418, Doi:10.2514/..28461.

[22] BORS,D., CUMMINS,J., GOODPASTER,J.: The anatomy of a pipe bomb explosion: The effect of explosive filler, container material and ambient temperature on device fragmentation, Forensic Science International, 2014, Vol.234, pp.95-102.

[23] BORS,D., CUMMINS,J., GOODPASTER,J.: The Anatomy of a Pipe Bomb Explosion: Measuring the Mass and Velocity Distributions of Container Fragments, Journal of Forensic Sciences (Wiley-Blackwell), Jan 2014, Vol.59, No.1, pp.42-51.

[24] LIBARDI,J., RAVAGNANI,S.P., MORAIS,A.M.F., CARDOSO,A,R.: Study of plasticizer diffusion in a solid rocket motor's bondline, Journal of Aerospace Technology and Management, Jul. - Dec. 2009, Vol.1, No.2, pp.223-229.

[25] RADULOVIĆ,J.: Qualitative and Quantitative Assessment of Bond Strength of Solid Rocket Propellant and Thermoplastic Material for Cartridge Loaded Grain, $7^{\text {th }}$ International Scientific Conference on Defensive Technologies OTEH 2016, 06.-07. October 2016, Belgrade, SERBIA, Proceedings, ISBN 978-86-81123-82-9, pp.659-664.

[26] ASTM D 905: Standard Test Method for Strength Property of Adhesive Bond in Shear by Compression Loading, ASTM Committee of Standards, Philadelphia, 2013.

\title{
Uticaj vremena na karakteristike spoja između ekstrudirane PVC cevi i livenog HTPB/IPDI raketnog goriva
}

\begin{abstract}
U radu je razmatrana mogućnost korišćenja termoplastičnog materijala kao inhibitora za čvrsto gorivo u dužem vremenskom periodu. Osnovna tačka ovog razmatranja je analiza karakteristika spoja ekstrudirane PVC cevi i livenog HTPB/IPDI raketnog goriva ispitanih odmah posle izrade uzoraka i posle dužeg vremena skladištenja. Struktura poli(vinil hlorida), tehnologija ekstruzije, hidroksi terminiran polibutadien i tehnologija livenja su opisani. Ispitane karakteristike uzoraka spoja ekstrudirana PVC cev-liveno HTPB/IPDI gorivo su jačina spoja i vizuelni izgled razdvojenih delova. Određivanje jačine spoja i vizuelnog izgleda pomenutih spojeva izvršeno je na temperaturama $20^{\circ} \mathrm{C} \mathrm{i} 50^{\circ} \mathrm{C}$. Ove karakteristike spoja ekstrudirana PVC cev-liveno gorivo na bazi HTPB/IPDI su određene kod sveže pripremljenih uzoraka i kod uzoraka posle pet godina skladištenja u magacinskim uslovima na obe gore navedene temperature.
\end{abstract}

Ključne reči: polimerni materijali, polivinilhlorid, hidroksiterminirani polibutadien, ekstruzija, cev, termoplastični materijali, čvrsto raketno gorivo, liveno gorivo, inhibitori, spoj, starenje, uticaj vremenskog perioda. 


\title{
Влияние времени на характеристики соединения между экструдированной ПВХ трубой и жидким НТРВ/IPDI ракетным топливом
}

\begin{abstract}
В статье обсуждается возможность использования термопластичного материала в качестве ингибитора твёрдого топлива в течение более длительного периода времени. Основной темой этого рассмотрения является анализ характеристик соединения экструдированной трубы из ПВХ и литого НTPB/IPDI ракетного топлива, протестированных непосредственно после подготовки образцов и после длительного хранения. Здесь описаны структура поли(винилхлорида), технология экструзии, полибутадиен с концевыми гидроксильными группами и литьё. Проверенными характеристиками совместных образцов экструдированного ПВХ-литого топлива НТРВ / IPDI являются прочность соединения и внешний вид отделенных деталей. Определение прочности соединения и визуальный внешний вид указанных соединений проводили при температуре $20^{\circ} \mathrm{C}$ и $50^{\circ} \mathrm{C}$. Эти характеристики сцепления экструдированной ПВХ-трубы и литого топлива на основе НTPB / IPDI были определены для свежеприготовленных образцов и образцов после пяти лет хранения в складских условиях при обеих вышеуказанных температурах.
\end{abstract}

Ключевые слова: полимерные материалы, поливинилхлорид, гидрокситерманированный полибутадиен, экструзия, труба, термопластичные материалы, твёрдое ракетное топливо, литое топливо, ингибиторы, соединение, старение, влияние периода времени.

\section{Influence du temps sur les caractéristiques du joint entre le tube PVC extrudé et du propergol de fonte HTPB/IPDI}

\begin{abstract}
Dans ce papier on considère la possibilité d'utilisation des matériaux thermoplastiques comme les inhibiteurs pour les propergols solides pendant une longue période de temps. Le point de base de cette considération est l'analyse des caractéristiques du joint de tube extrudé en PVC et du propergol de fonte HTPB/IPDI examiné immédiatement après la fabrication des échantillons et après un long temps de stockage. La structure de poly (vinyle chlorure), la technologie d'extrusion, le polybutadiène hydroxi terminé et la technologie de fonte ont été décrits. Les caractéristiques des échantillons du joint examinés du tube PVC extrudé et du HTPB/IPDI de fonte de propergol sont la force du joint et l'aspect visuel des parts séparées. La détermination de la force de joint et l'aspect visuel des parts citées a été faite aux températures de $20^{\circ} \mathrm{C}$ et de $50^{\circ} \mathrm{C}$. Ces caractéristiques du joint de tube PVC extrudé et du propergol à la base de HTPB/IPDI ont été déterminées chez les échantillons préparés frais et chez les échantillons après cinq ans de stockage dans les conditions de dépôt aux températures déjà citées ci-dessus.
\end{abstract}

Mots clés: matériaux polymères, polyvinyle chlorure, polybutadiène hydroxi terminé, extrusion, tube, matériaux thermoplastiques, propergol solide, propergol de fonte. 